\title{
The Omani Coastal Traditional Sardine Fishery 1994-2007: A Review
}

\author{
Saud Al-Jufaili" ${ }^{1 *}$ and Omar S. Al-Jahwari² \\ ${ }^{1}$ Department of Marine Science and Fisheries \\ College of Agricultural and Marine Sciences, Sultan Qaboos University \\ P.O. Box 34, Al-Khod 123,Muscat, Sultanate of Oman \\ ${ }^{2}$ Oman Fisheries Company, P.O. Box 2900, Ruwi 112, Sultanate of Oman
}

\begin{abstract}
هـراجعـة لمصايد أسـماك السـردين العـمانية التقليدية (1994-2007)
د.ســود الجـفيلي و عـمـر الجههوري

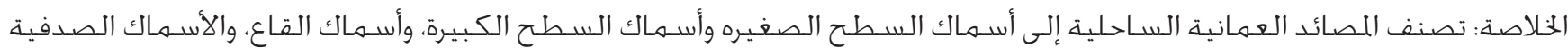

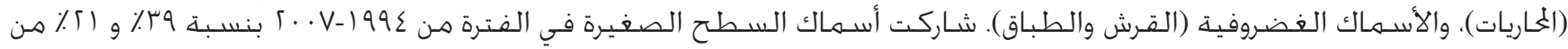

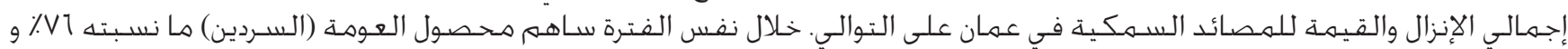

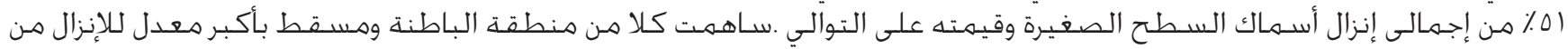

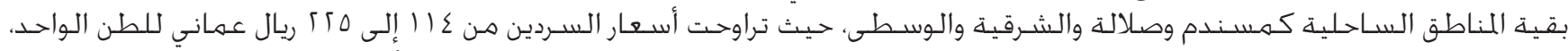

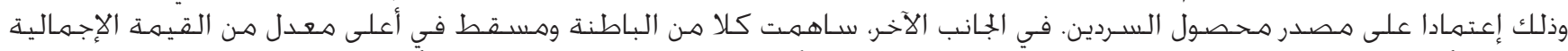

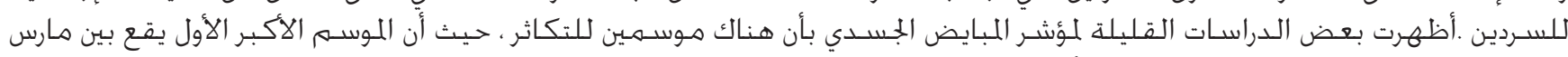

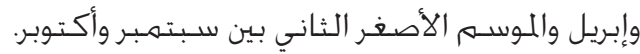

ABSTRACT: The Omani coastal fishery is categorized into small pelagics, large pelagics, demersals, shellfishes, and sharks and rays. During the period 1994-2007 the small pelagics contributed 39 and 21\% to the total Omani fisheries landings and values respectively. During 1994-2007 sardines alone contributed 76 and 51\% to the total small pelagics landings and values, respectively. Al-Batina and Muscat regions contributed the highest to the total landings; among other Omani regions, Musandam, Muscat, and Sharqiya and Al-Wusta regions. Total sardines prices ranges from 114 to 225 Omani Rials per ton depending on where the sardines are coming from. On the other hand, Al-Batina and Muscat regions contributed the most in the total sardine values. Few gonadosomatic index studies indicated two major spawning peaks: a major one occurred during March-April and a minor one in September-October.

Keywords: Oman, sardine, landings, values, Musandam, Batina, Muscat, Sharqiya, Wusta, Dhofar.

\section{Introduction}

The Sultanate of Oman has a far richer and longer coastline in comparison to its neighbors. Oman's coastline is approximately 3,165 kilometers long and is divided into six different coastal regions, from North to South - Musandam, Batina, Muscat, Sharqiya, Wusta, and Dhofar (Fig. 1). Fish resources in Oman are considered as one of the most important contributors to the national economy. Huge marine resources exist and fishermen primarily exploit these resources. Fisheries activities in Oman can currently be classified as traditional and industrial (Stengel and AlHarthy, 2002).

Sardine landings are reported normally by the Ministry of Agriculture and Fisheries Wealth as one of two categories: Indian oil sardine, Sardinella longiceps landings, and total other sardine landings, which include all other sardine landings apart from the Indian oil sardines. To avoid error in reporting the results the current study combines all the sardines and Indian oil sardines referred to in the current study as the total sardine landings. Two reasons can be given for this grouping: first, 95\% of the landings are from the Indian oil sardines (Dorr, 1990), and second, because of the difficulty in the field of differentiating the different sardine species from each other.

The current work reviews the 1994-2007 Omani sardine traditional fishery along the Omani coast.

\section{Materials and Methods}

Historical data from the fisheries annual statistical reports published by the Oman Ministry of Agriculture and Fisheries Wealth were reviewed and analyzed. A number of fishermen were also interviewed along the coast of Oman from AlBatina to Dhofar regions. Different fish markets and landing sites along the coast were also visited including Mutrah, Seeb, Barka, Sohar, and Salalah. 


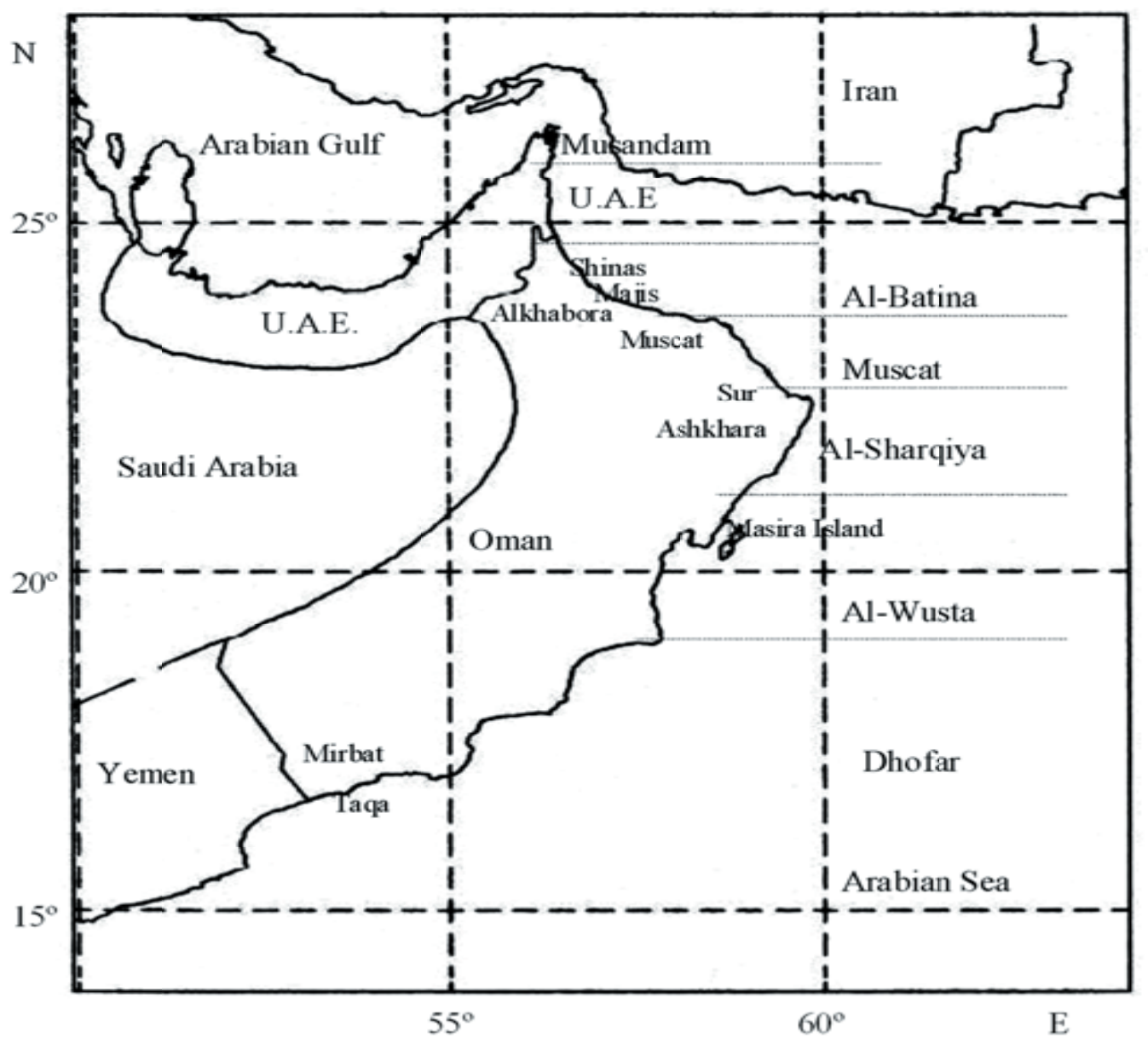

Figure 1. Map of Oman showing the regions mentioned in the text.

\section{Results and Discussion}

Sardinella longiceps or Indian oil sardine (family clupeidae) is a small fish with a maximum size of $23 \mathrm{~cm}$. $S$. longiceps is a planktivore, with diatoms, dinoflagellates and copepods as favourite food items. Dorsal rays 16-17, anal rays $14-16$, pectoral rays 17 , pelvic rays 9 (8 in the other Oman sardinella); longitudinal scale series 45-48; ventral scutes 31-32, not well developed; gill rakers 150233 (in fish larger than $6 \mathrm{~cm}$ standard length); body depth usually 4-4.9 in standard length; body less compressed than other Oman sardinella and more round-bellied; head long, 2.9-3.4in standard length; greenish on back with iridescence, silvery on side and ventrally; a small black spot at edge of opercle at eye level; usually a brassy blotch above upper end of gill opening (Randall, 1995).

All sardines other than the oil sardine were placed in this group. Their maximum size ranges from 14 $\mathrm{cm}$ White sardinella (Sardinella albella) to $27 \mathrm{~cm}$ Spotted sardinella (Amblygastersirm). Like the Indian oil sardine, other sardines feed mainly on a variety of plankton (Randall, 1995). This group includes Spotted sardinella (Amblygastersirm), Fourspot sardine (Herklo tsichthysquadrimaculatus), White sardinella (Sardinella albella), Goldstripe sardinella (Sardinella gibbosa), Blacktipsardinella (Sardinella melanura), Sind sardinella (Sardinella sindensis), White sardine (Escualosa thoracata), Rainbow sardine (Dussumieria acuta) and Slender Rainbow sardine (Dussumieriaelopsoides).

Gonadosomatic index and relative weight trends and Elefan analysis confirmed occurrence of two spawning peaks, a major one during March-April and a minor one, in September-October (Siddeek et al., 1994; Dorr, 1991). The ratio of male to female fish was nearly $1: 1$. Fecundity ranged from 8,000 to 108,000 . Variability in the number of eggs per fish increased with the size of the fish.

\section{Fishery}

The fish landings in Oman are grouped into five different categories. These are small pelagics, large pelagics, demersals, shellfishes, sharks and rays. During the period 1994-2007 the total Oman fish landings was 1,569,553 $\mathrm{mt}$ of fish and the total value was 7,334,493 OR. The average total landings in the aforementioned period was as follows: demersal 22\%; large pelagics 30\%; small pelagics $39 \%$; shellfishes $5 \%$; sharks and rays $4 \%$. On the other hand, the contribution of different fish categories to 


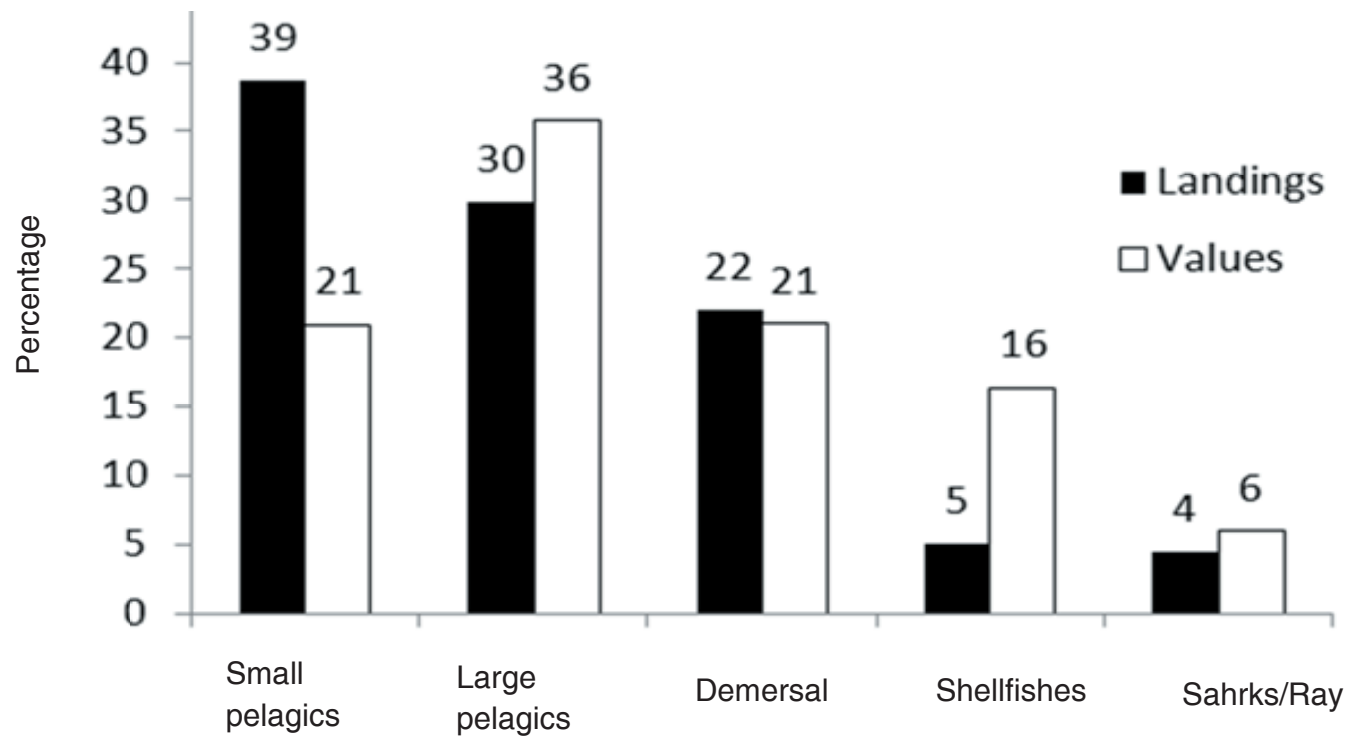

Fish Categories

Figure 2. Percentage of average total landings for different fish categories landings in Oman (1994-2007).

the average total values in the same period were shellfish $16 \%$; sharks and rays $6 \%$; demersals $21 \%$; small pelagics $21 \%$; and large pelagics $36 \%$ (Fig. 2).

Small pelagics includes sardines, Indian mackerel, anchovies, small jacks, mullets, needle fish, and "other small pelagics" (a mixture of different small pelagics). During the period 1994-2007 sardines contributed $76 \%$ to the total small pelagic landings versus all other small pelagic, while it contributed $51 \%$ to the total values within the same period (Fig. 3).

Sardines are distributed all along the Omani coast. They are caught in all regions of Oman (Fig. 1) by using the same type of gear: beach seine, purse seine and, occasionally, cast nets, which require little effort but are rarely deployed far from the beach. Beach seines and purse seines are modified gillnets that require up to 12 people to set and haul. The fishermen can catch from 30-40 tons a day when the sardines are plentiful. Beach seines, in general, are the most common type of gear used for sardines (Al-Jufaili et al., 2006).

In the Al-Wusta and Dhofar regions, the fishermen stop fishing for sardines during the monsoon season (June to August) when the sea conditions are too rough for fishermen to operate their traditional gear. But not all the fishermen follow this pattern. In some places, for example, in the Dhofar region fishermen still fish for

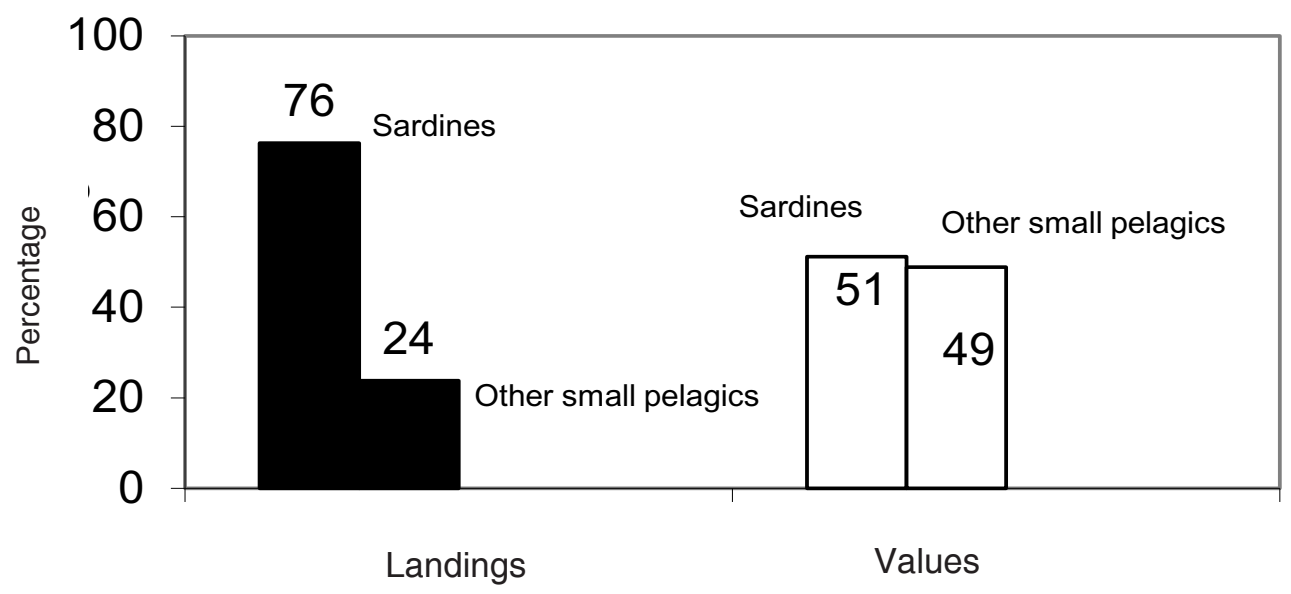

Figure 3. Contribution of sardines versus all other small pelagics in percentages in landings (black) and values (white) during the period 1994-2007. 


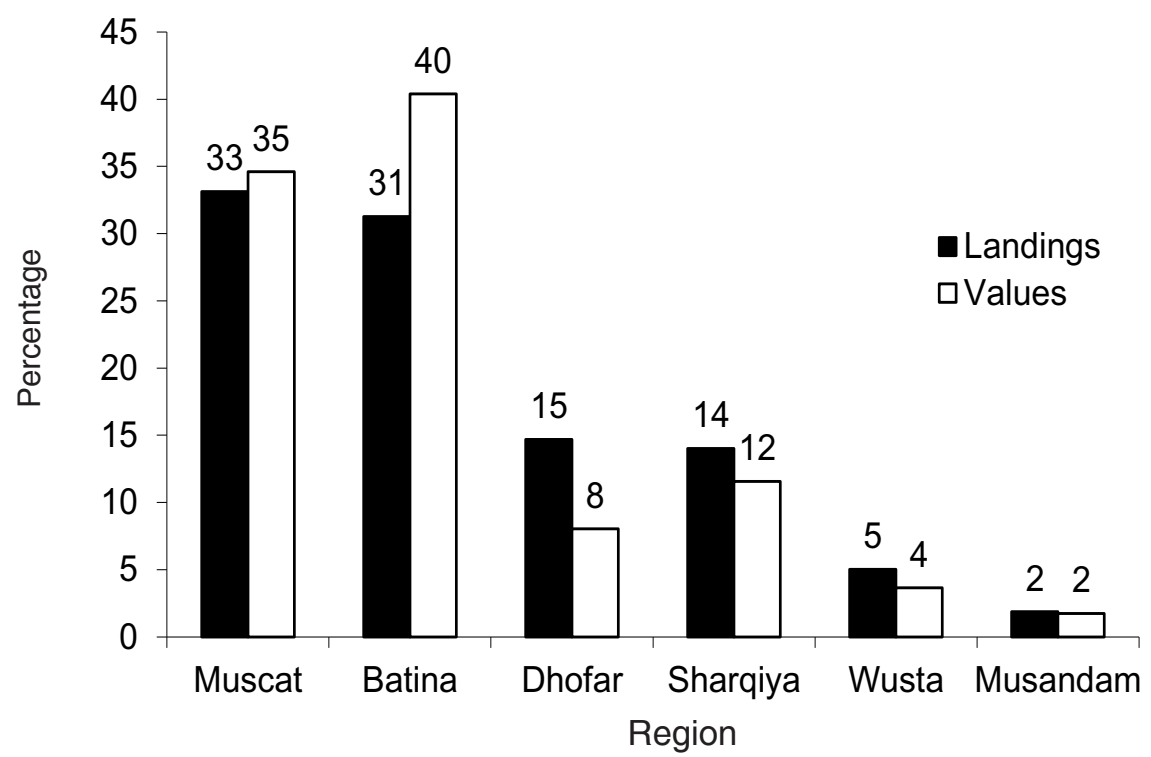

Figure 4. Annual percentage contribution (landings and values per region) of sardines to the total Omani small pelagic group (19942007).

sardines even during the monsoon. These places are normally not affected and fishermen can still continue fishing normally.

Figure 4 shows the annual percentage contribution (landings and values per region) of sardines to the total Omani small pelagic group (1994-2007). It can be seen in Figure 4 that the Muscat region is the highest contributor with $33 \%$, followed by Batina and Dhofar with 31 and $15 \%$, respectively. In terms of value, sardines are more valued in Batina, which contributes $40 \%$ to the annual total value, while Muscat contributes $35 \%$. The other regions contribute only $25 \%$.

\section{Average Monthly Landings}

Based on a five year data series, sardine landings in Oman start to pick up from November and start to drop again from March. The landings reach their peak in February (Fig. 5).

The contribution of the major sardine fisheries, AlBatina and Dhofar, to the total sardine landings in Oman have been declining since 1994 (Fig. 6). On the other hand, the contribution from the minor sardine fisheries, Al-Wusta, Al-Sharqiya, and Musandam has been slowly increasing since 1999. The fluctuations in the all Omani landings are directly proportional to those of the sardine landings.

Various factors affect the amount of fish being caught over a set period of time. Important amongst these are the habits of the fish themselves, the weather and the state of the sea. For fishing with the beach seines, the shoals must come sufficiently close to shore to be able to be surrounded by the net and the wave height must be low

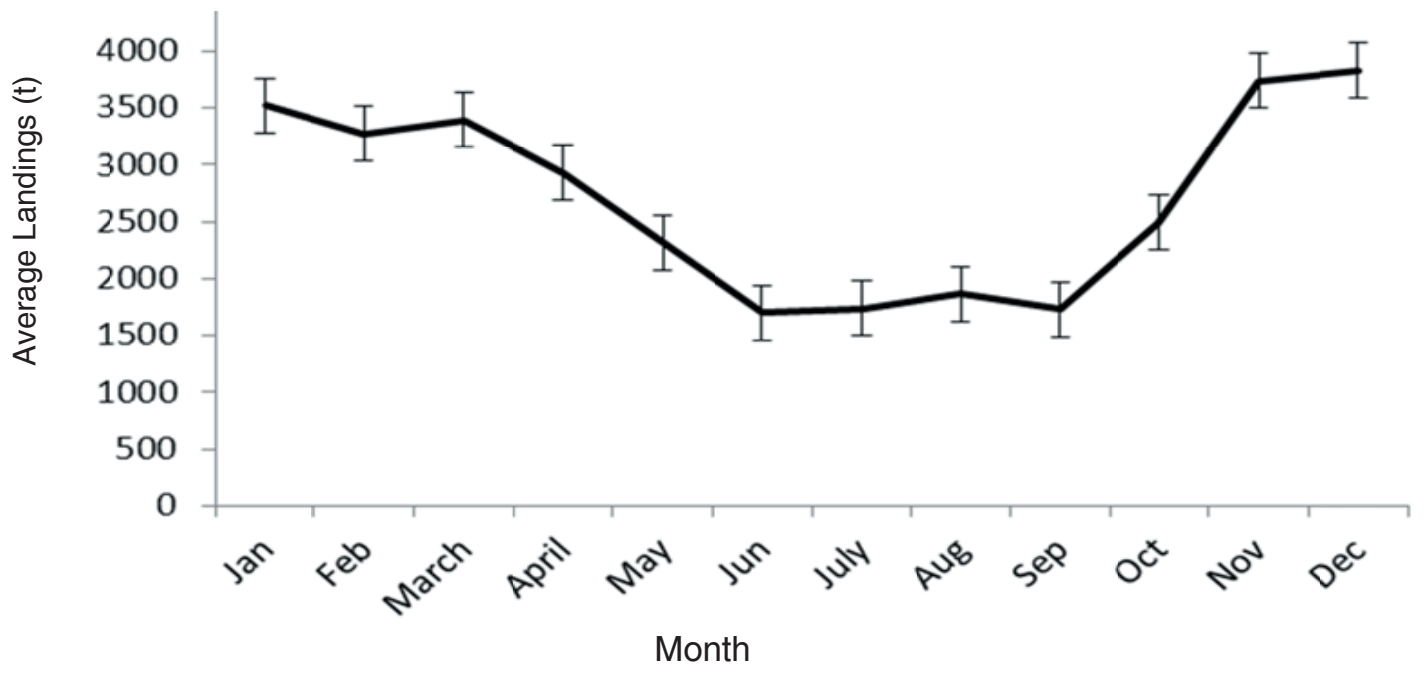

Figure 5. Monthly average total sardine landings (1994-2007). 


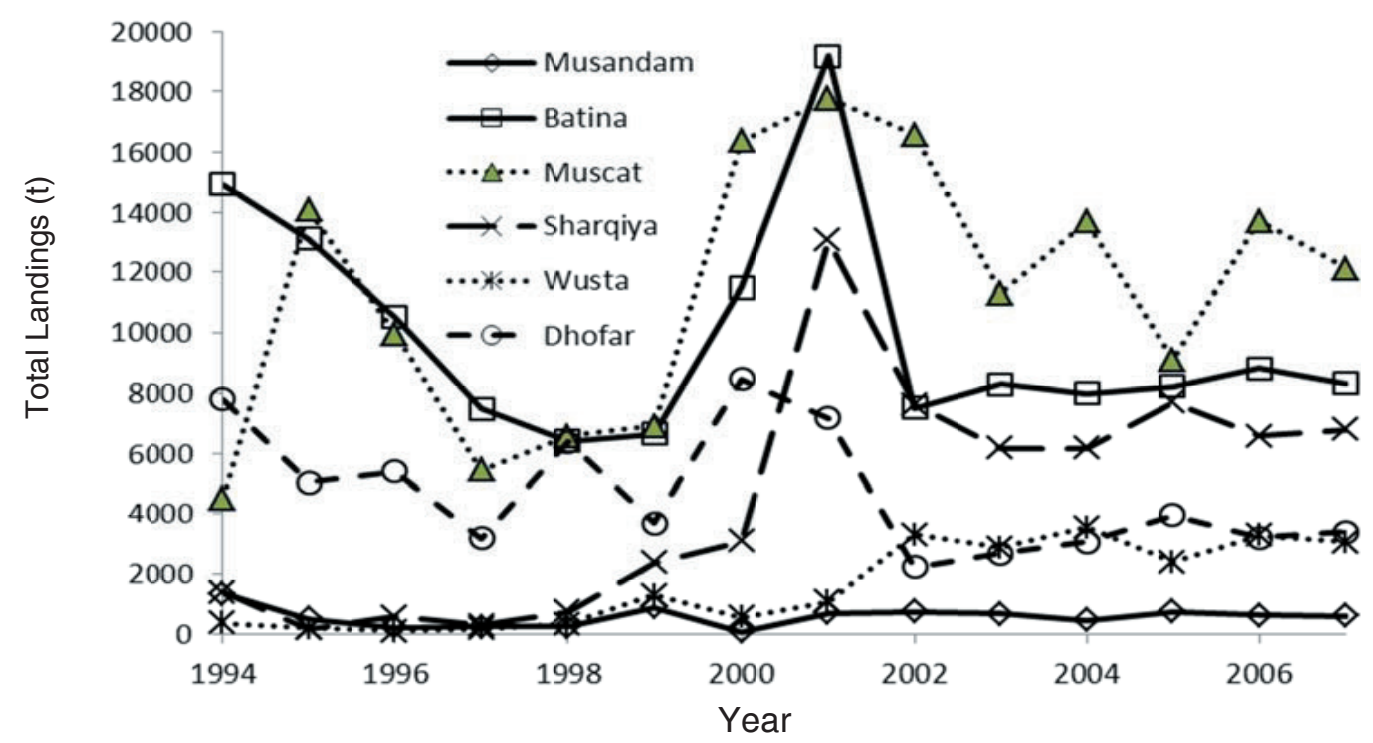

Figure 6. Landings per region contribution to the Omani total sardines landing in the period 1994-2007.

enough for operation of the net. The weather must also be dry enough for the fishermen to think that they will be able to dry the fish if they catch it (MAF, 1991).

Al-Batina and Muscat regions contributed the most to the total sardine values. The values contributed from these two regions have been inversely related since 1995. The overall slope of values is slowly decreasing. Dhofar also had a negative slope and was inversely related to the values contributed by Sharqiya region since 1999. The contribution from Sharqiya, Wusta, and Musandam has been gradually and slowly increasing over the last 10 years (Fig. 7). The small pelagic species, and particularly sardines, are abundantly present in Batina and Dhofar.
In Batina and Muscat there were more than 230 beach seines in 1994. For Salalah the sardine is localized in Taqah, Dahariz, AL Haffa, Raysut and Mughsail, where beach seines and cast nets are used. The catch is dried on the beach or in drying yards. Sardine and anchovy are exploited during the fishing season by beach seines in the Batina and Muscat regions and jointly by cast nets in Dhofar. Some skiffs landing in Muttrah use surrounding gillnet during most of the year and their catch is used for human consumption. Beach seine and cast nets landings are dried and used for animal feeds. In Sharqiya and Wusta regions cast nets are used for catching sardines. Some of the landings are dried and some are traded as

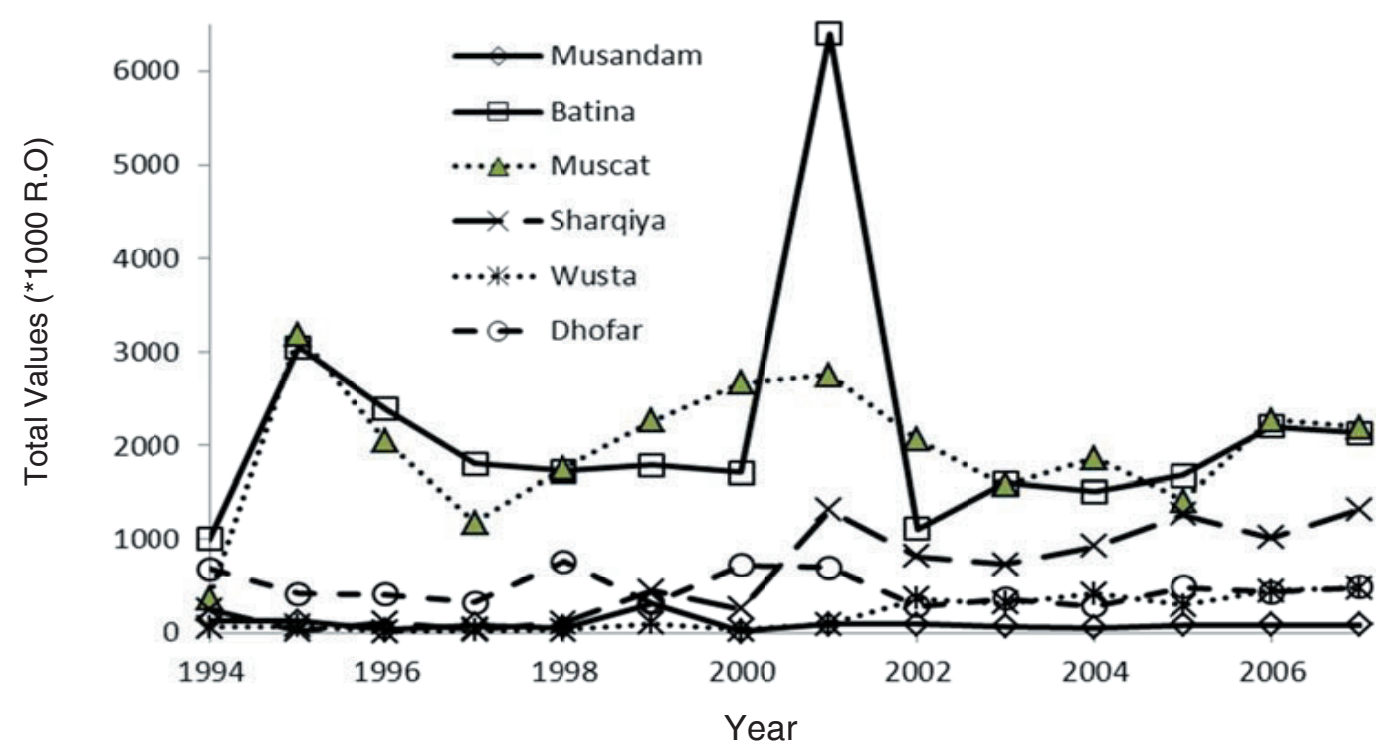

Figure 7. Landings contribution to the total sardines values in the period 1994-2007. 


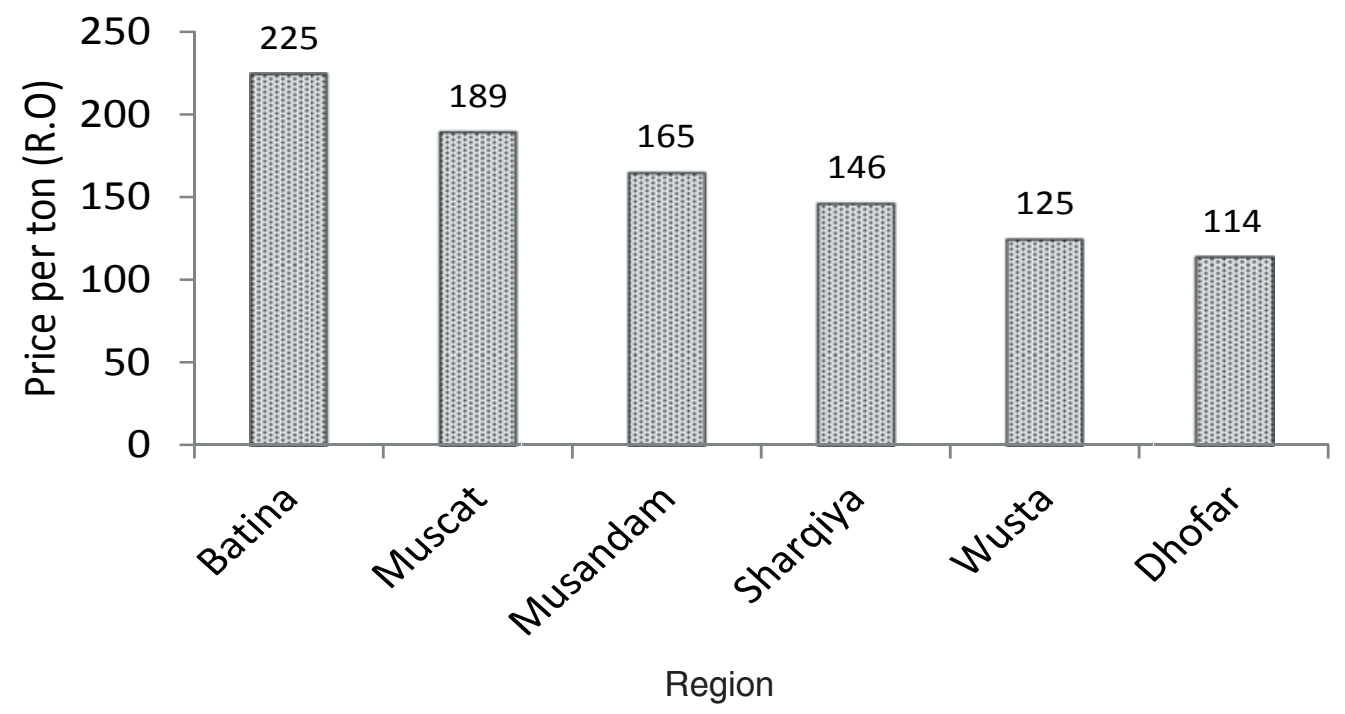

Figure. 8. Average sardines prices per ton from 1994-2007.

fresh sardines for human consumption. In the Musandam region sardines and anchovy caught by beach and cast net are dried in Dabba and Khasab in bags for animal feeds. Along the Oman coastline a daily catch of sardines is undertaken using cast nets and the products are used as bait.

\section{Price Per Ton}

The Batina region has the highest price per ton of sardines (225 R.O), while the price ranges from 114 to 189 R.O in the rest of the regions (Fig. 8).The price of sardines in Batinah and Muscat are higher because the human population is higher (28.1 and $27 \%$, respectively) than in any region due to the large animal resources in this region. Dried sardines in Dhofar are mainly used for animal feed. The price finding by the current resources supported those found by the Ministry of Agriculture and Fisheries in 1994 (MAF, 1994).

\section{Sardine Discard}

Total sardine discard for the year 1992, according to the fishermen observers, was estimated to be 52.943 tons. The amount of discarded sardines increased in 1993 to 165.726 tons, but in 1994 the amount of discarded sardines decreased to 84.029 tons (Fig. 9). The quantity of discard then fell steadily each year by several tons until it reached zero in 2001. This decrease was due to the fisheries programs run by the Ministry of Agriculture and Fisheries Wealth. In addition, more selective gear was introduced to reduce the by-catch (Harrington et al., 2005).

\section{Drying Sardine}

The primary species of sardine caught for drying in the Sultanate of Oman is the Indian oil sardine, Sardinella longiceps, although two other species, S. gibbosa and
S. sindensis are also found in the catch, especially on the Batina coast. Sardines have been traditionally dried in Oman for hundreds of years on the beach under the direct sun, (Mahgoub et al., 2005). At present the sardines are used by traditional herdsmen to supplement natural fodder during the dry season, and they form an important source of protein and fat during this period. The prices paid depend upon the seasonal availability of the fish, as well as the availability of natural feed. The quality of the product is rarely a significant influence on the final price. According to a report (MAF, 1995), small pelagic landings in Oman, for example, were 41,496 tons, $80 \%$ of which were sardines $(33,054$ tons). Total dried sardines were 33,000 tons. Only a small amount was used for human consumption and for export. It appears that there is a sufficient supply of sardines (i.e.23,000 tons/year) to support the livestock feed industry, thus allowing for the utilization of this product on a commercial scale.

Sun-drying of fish is a traditional practice in many parts of the world. A major problem with traditional sundrying of sardines, however, is the loss of dried products due to rats, cats, dogs and birds, and insect infestation. Also, goats and cattle will eat the sardines during the drying period without supervision (Figs. 10a and b). This loss can reach up to $30-40 \%$. These factors combine to reduce fishermen's revenues from sardines. In the Gulf, sardines are traditionally dried by spreading them out on a sandy beach for about a week in winter and 4-5 days in the summer, depending on the meteorological conditions. During this time, the only form of management is to turn the fish on the third day.

This method has slow drying rates and so the fish are prone to contamination. The slow rates of drying are a result of the fact that fish laid directly on the ground can dry from one side only and wind speeds at ground level are 


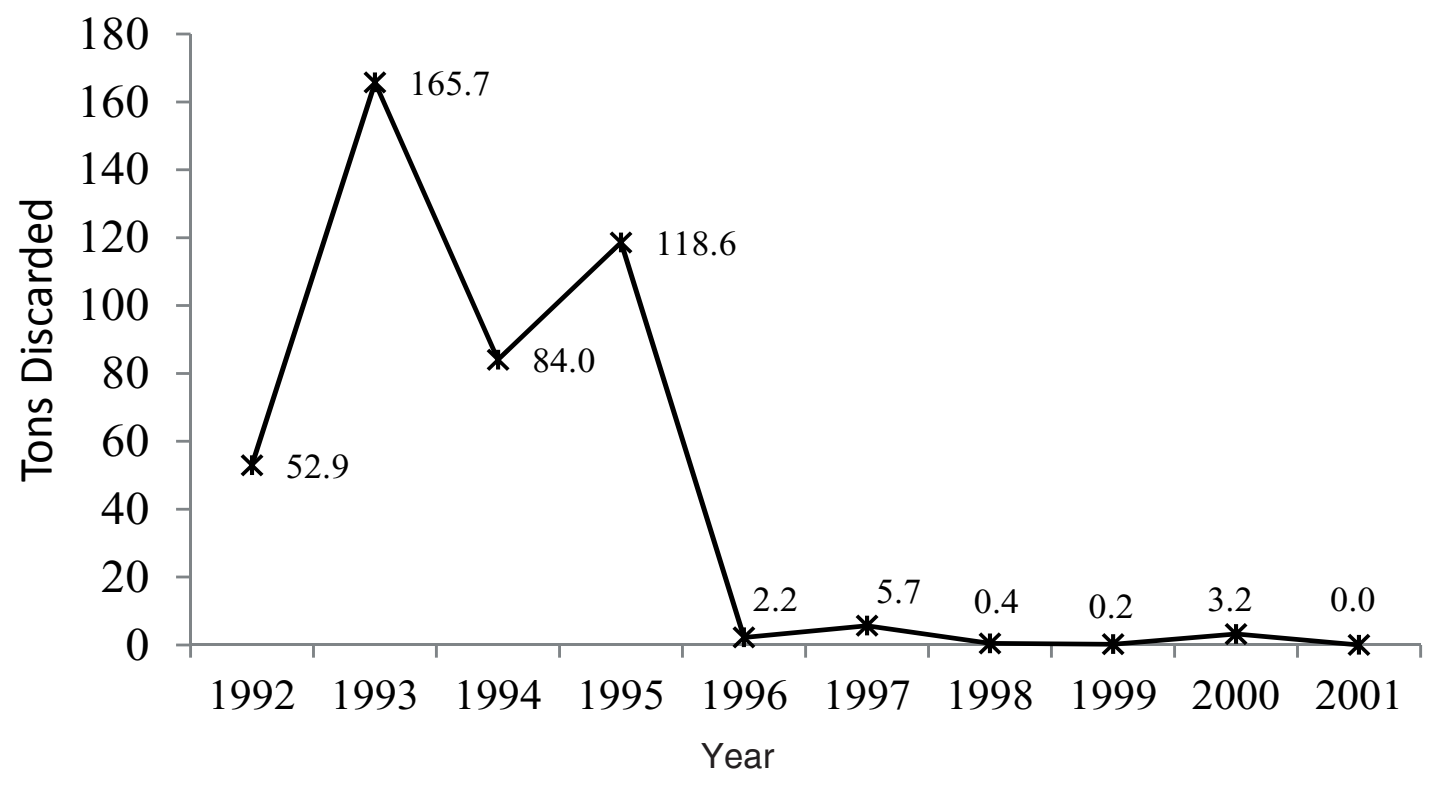

Figure 9. Total sardines discarded (1992-2001) according to fish observers reports (data provided by MAF).

(a)

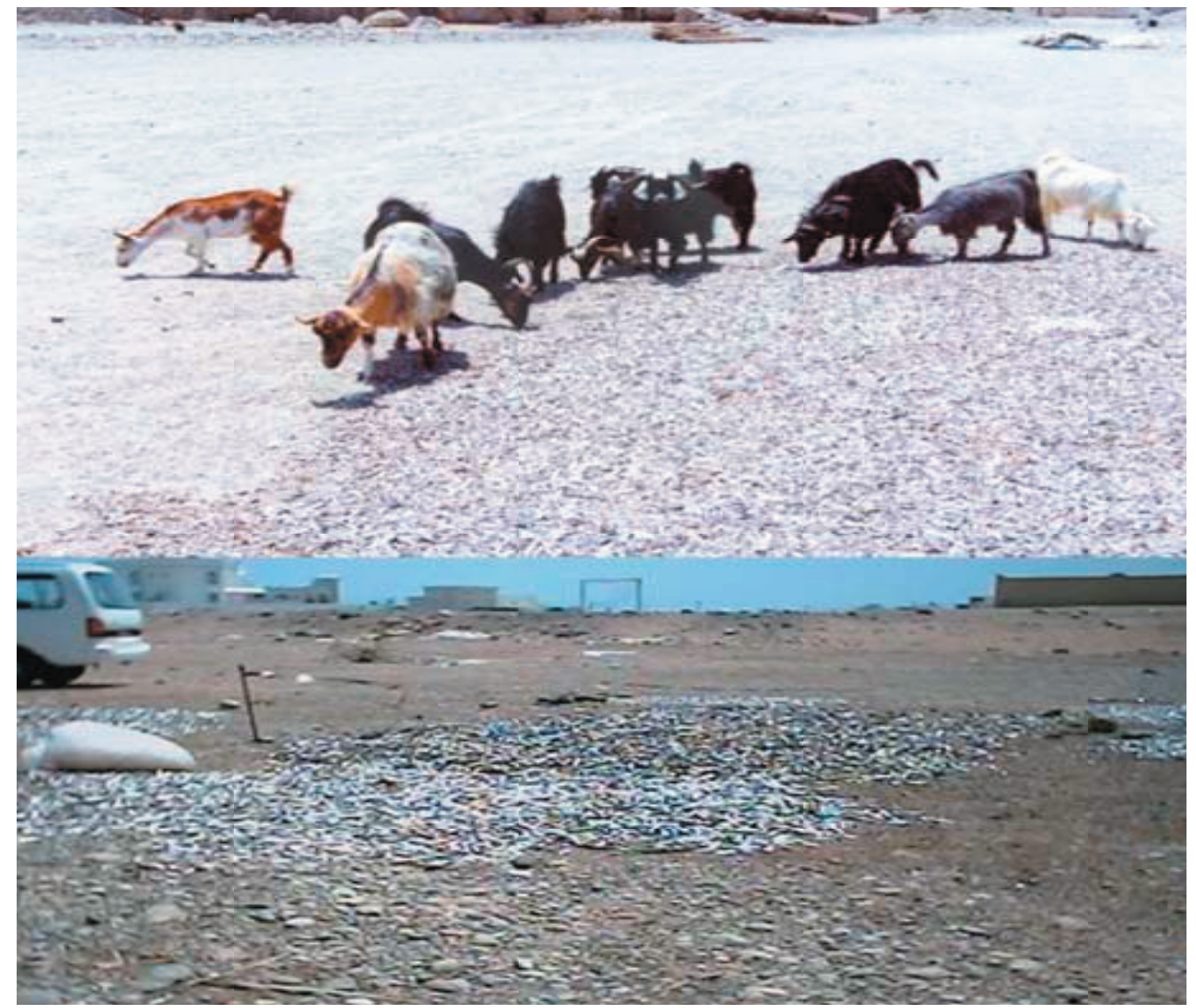

Figures 10a and b. Sardines drying on the ground. 


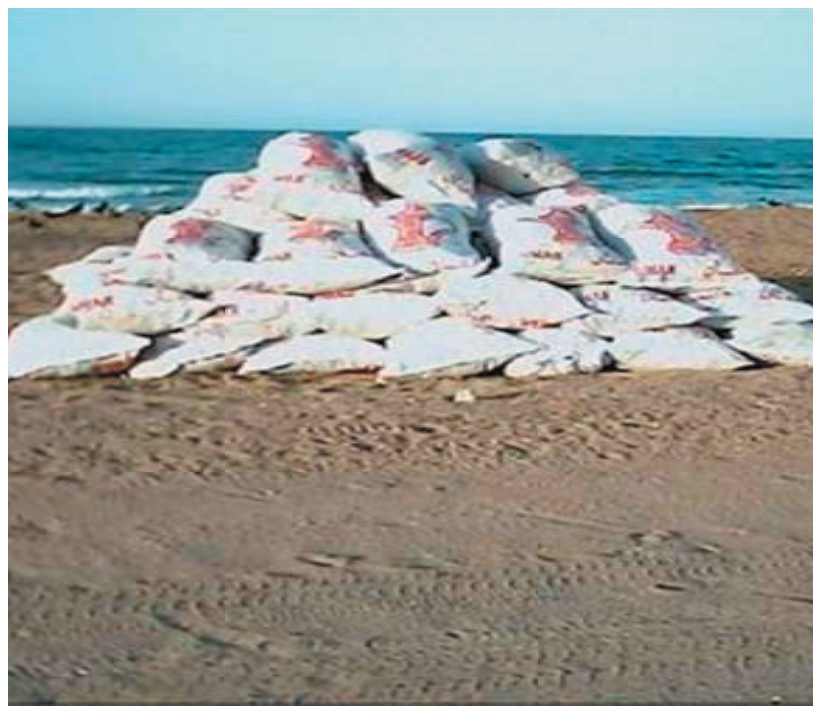

Figure 11. The bags of dried sardines are stacked on the beach together.

very low (almost zero). The contamination of the product is a result of contact between the fish and the ground and probably the carrying of microbial contaminants by flies attracted to the slowly drying fish (Fig. 10b).

After drying, the fish are packed into bags for storage and distribution. Each bag is filled with about $20 \mathrm{~kg}$ of dried fish. No scales are used to measure the quantity of fish in the bag. After packing, the tops of the bags are sown together with wire. The bag is used as the sales unit and prices are fixed between buyer and seller on this basis.

The delay between production and sale from the driers to the traders is usually relatively short. Often the fish is sold before the drying process is completed since they are on the ground for about a week and itinerant buyers will arrange to purchase and collect the product in advance of the fish being completely dry. For this reason the fish driers do not normally have any specialized storage facilities. When storage is necessary the bags of dried fish are stacked together, sometimes on wooden boards, on the beach (Fig. 11) and covered with a waterproof tarpaulin until a buyer is found. In the Dhofar region dried fish is sold in bulk from the area of dried fish on the ground or by the truck load. Farmers themselves usually come to buy fish and negotiate prices and purchases before or whilst the fish are being dried. Once dry, the purchaser loads the fish onto the back of his truck or pickup and takes it back to his farm.

Sardines are sometimes brought from beach to the drying field by Landrover pickup or more frequently by 3 or 5 ton lorries. The costs of production with the existing technique of drying fish directly on the ground, with little or no previous preparation, are currently very low. Working costs, such as transport, labour and packaging contribute to a major part of the outlay involved in production, but are themselves minimal. However, the end-product prices are high, especially when considering the generally poor quality in comparison to equivalent imported fish meals. Since the act of drying does not actually increase the value of the fish, the high value largely reflects the high cost of raw material procurement. These include the capital cost and high depreciation on boats and equipment, the large number of people involved in operating the beach seine, as well as the upkeep of vehicles in the salty environment. Prices are rarely raised for superior quality products, this inspection simply ensuring that sacks of poor quality fish are rejected. Also, when landings become fewer and less reliable after February/March, prices will rise significantly as farmers compensate for the lack of available fodder. This situation is particularly acute during the early weeks of the monsoon season, before grass has a chance to sprout, although fishing is severely reduced because of rough seas. At this point, the few fish being landed will command a very high price. This situation is exacerbated during the monsoon season, when rough weather severely curtails fishing in the Dhofar region. Fortunately, with Batinah landings peaking over March to June and continuing until September supplies can generally be maintained. However, demand may rise to such a level that dried sardines may be brought in from other sources, including the Yemen and the UAE.

\section{Sardine Landings and Values by Region}

\section{Musandam}

In the period 1994-2007 the average total sardines landing in Musandam region was estimated to be $596 \mathrm{mt}$ with an average value of 93,000 Omani Rials. The highest recorded total landing was in 1994, which was $1,361 \mathrm{mt}$, (129,000 Omani Rials), and the lowest was in 2000 which was only $52 \mathrm{mt},(11,000$ Omani Rials). For the years 20012003 the landings were stable at an average of $695 \mathrm{mt}$ (83,000 Omani Rials)(Fig. 12). The sardines' values were the highest in 1999 when they were valued at 311,000 O.R for a total of $875 \mathrm{mt}$.

\section{Al-Batina}

In the period 1994-2007 the average total sardine landing in Al-Batina region was estimated to be $9,975 \mathrm{mt}$ with an average value of 2.152 million Omani Rials. The highest recorded total landing was in 2001, which was 19,181 mt, (6.395 million Omani Rials) and the lowest was in 1998 which was only $6,402 \mathrm{mt}$ (1.728 million Omani Rials). However, the highest valued landings were in 2001 which were valued at 6.395 million Omani Rials for a total of only $687 \mathrm{mt}$ (Fig. 13).

\section{Muscat Region}

In the period 1994-2007 the average total sardine landing in Muscat region was estimated to be 10,565 mt with an average value of 1.843 million Omani Rials. The highest recorded total landing was in 2001, which was $177,887 \mathrm{mt}$ (2.754 million Omani Rials) and the lowest was in 1992 


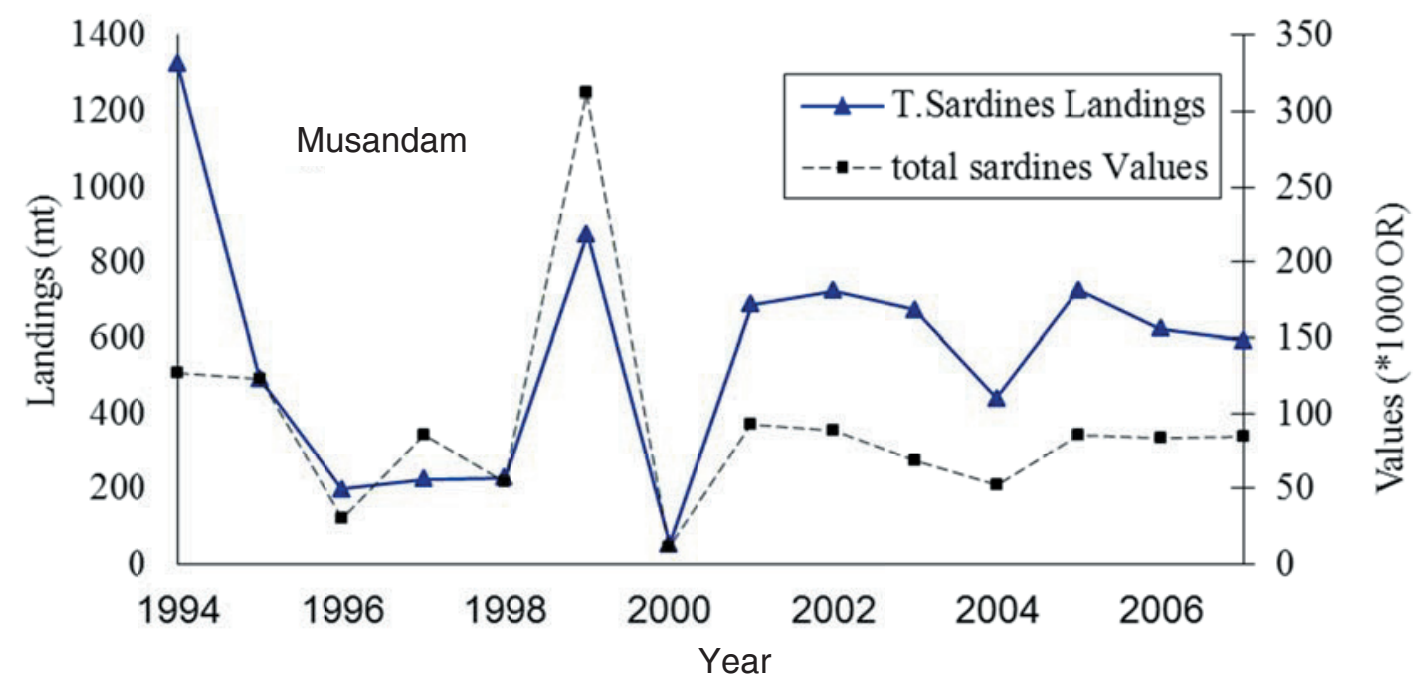

Figure 12. Total sardine landings (mt) and values (1000 R.O) in the Musandam Region from the period 1994-2007.

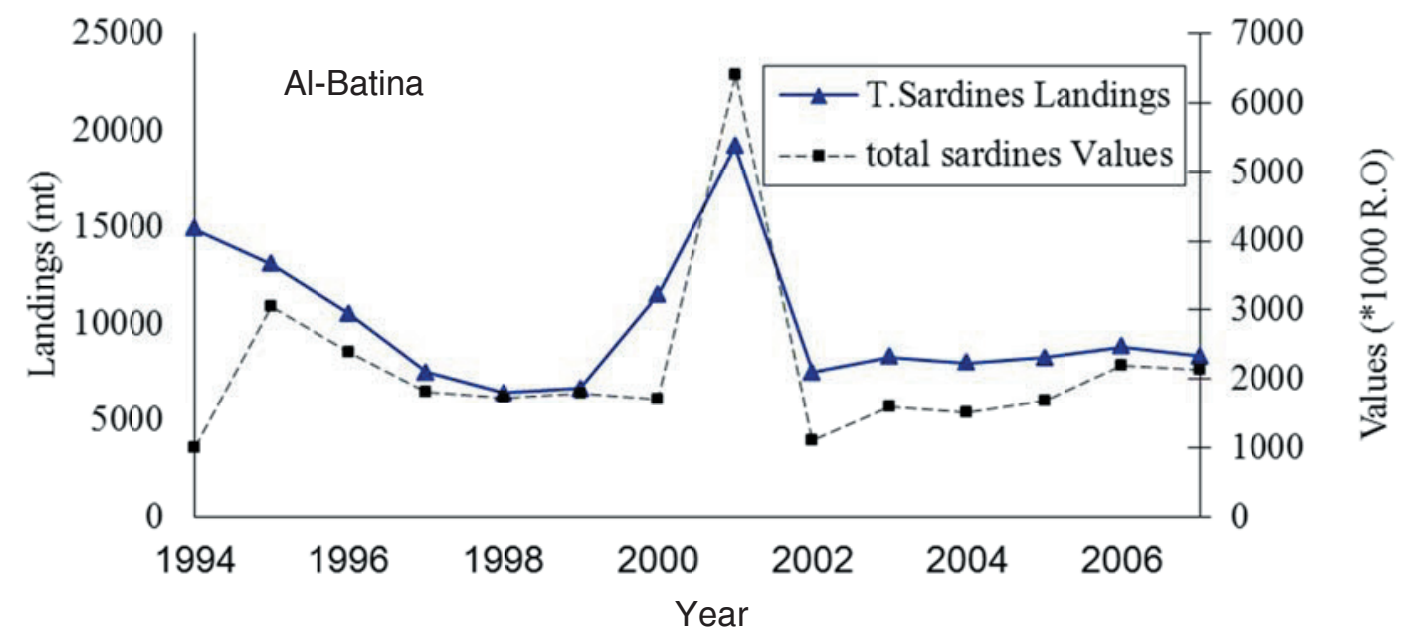

Figure 13. Total sardine landings (mt) and values (1000 R.O) in Al-Batina Region in the period 1994-2003.

which was only 2,520mt (163,000 Omani Rials) (Fig. 14).

\section{Sharqiya Region}

In the period 1994-2007 the average total sardine landing in Sharqiya region was estimated to be $4,474 \mathrm{mt}$ with an average value of 616,000 Omani Rials. The highest recorded total landing was in 2001, which was 13,071 mt (1.314 million Omani Rials), and the lowest was in 1995 which was only $164 \mathrm{mt},(19,000$ Omani Rials) (Fig. 15).

The quantity of sardines landed in Al-Sharqiya region was less than Al-Batina and Muscat regions because the fishermen at Al-Sharqiya believe that sardines are the primary food for the tunas and other valuable large pelagic fishes and so they rarely target sardines (Al-Jufaili et al., 2006). Also, the numbers of fishermen who work for the catch of sardines in Al-Sharqiya region are lower than Muscat and Al-Batina regions.

\section{Al-Wusta Region}

In the period 1994-2007 the average total sardine landing in Al-Wusta region was estimated to be $1,600 \mathrm{mt}$ with an average value of 195,000 Omani Rials. The highest recorded total landing was in 2004, which was 3,545 mt, valued only at 415,000 Omani Rials, and the lowest was in 1996 which was 92mt only, (11,000 Omani Rials) (Fig. 16).

\section{Dhofar Region}

In the period 1994-2004 the average total sardines landing in the Dhofar region was estimated to be $4,685 \mathrm{mt}$ with an average value of 462,000 Omani Rials. The highest recorded total landing was in 2000 , which was $8,469 \mathrm{mt}$, 


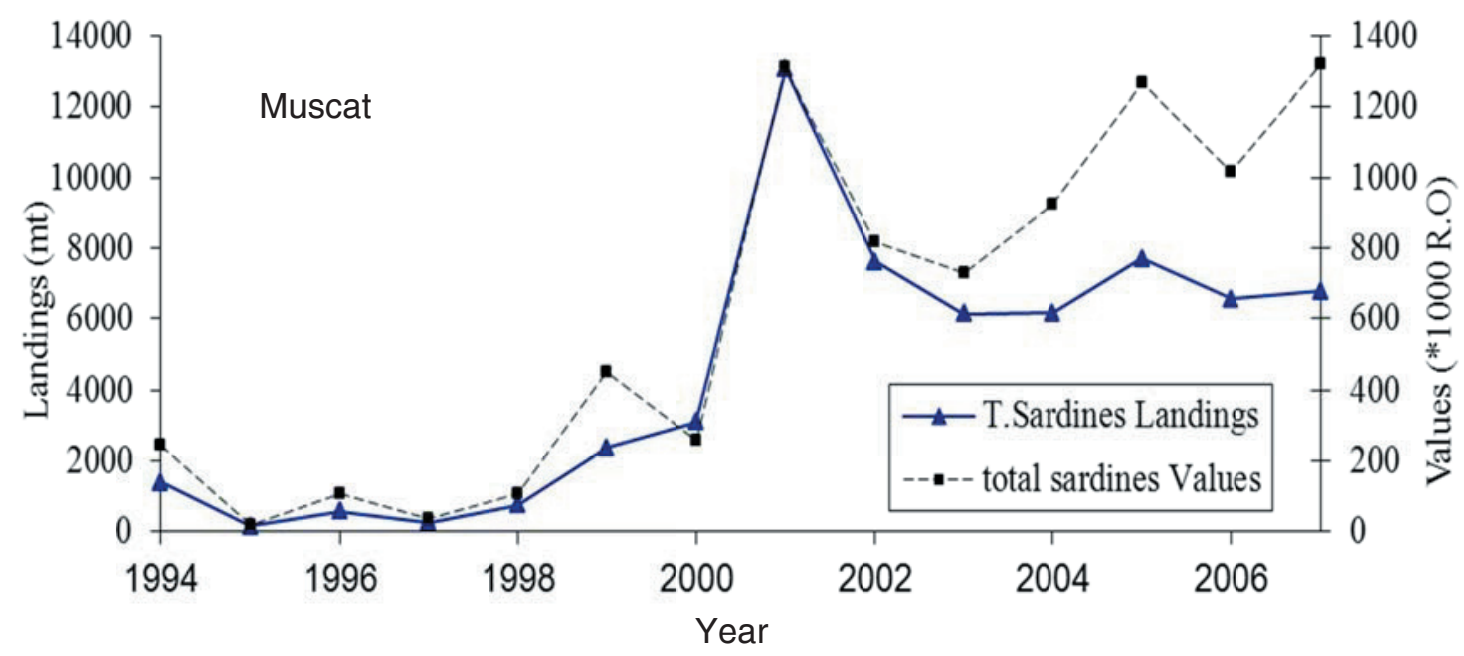

Figure 14. Total sardine landings (mt) and values (1000 R.O) in the Muscat region from the period 1994-2003.

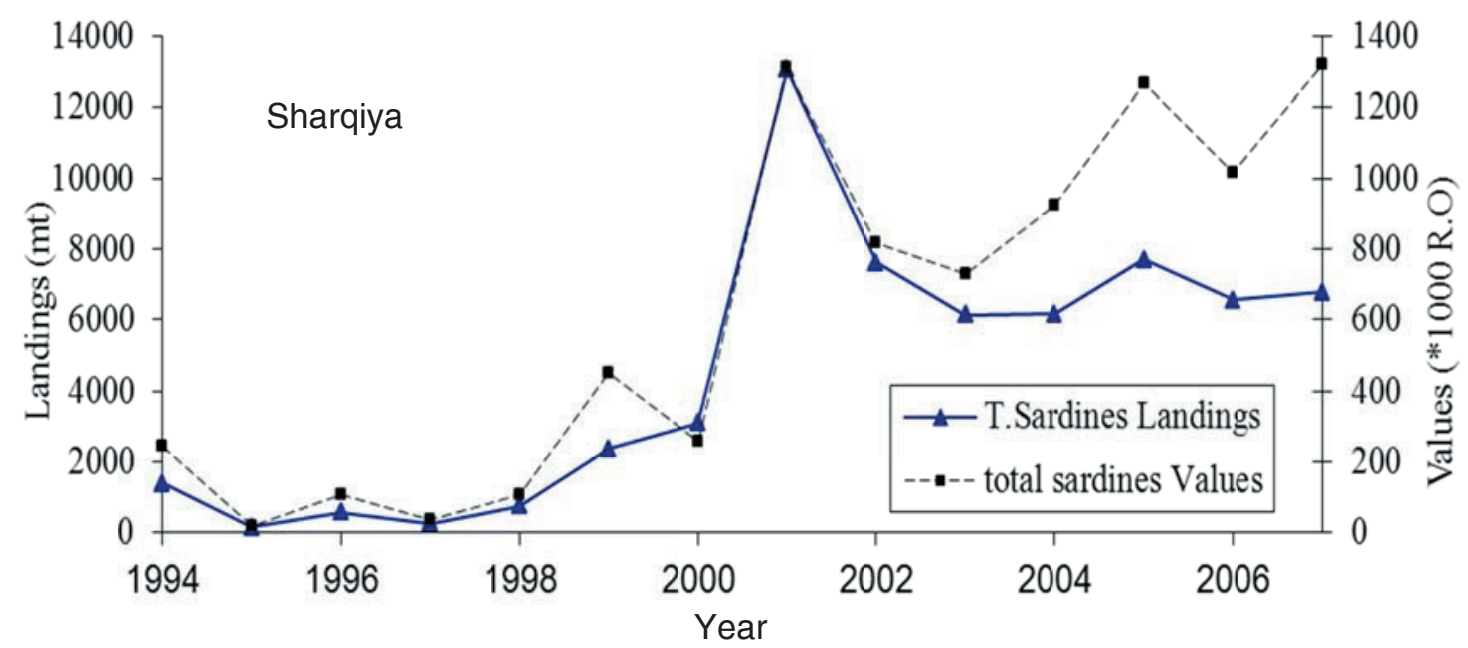

Figure 15. Total sardine landings (mt) and values (1000 R.O) in the Sharqiya region from the period 1994-2003.

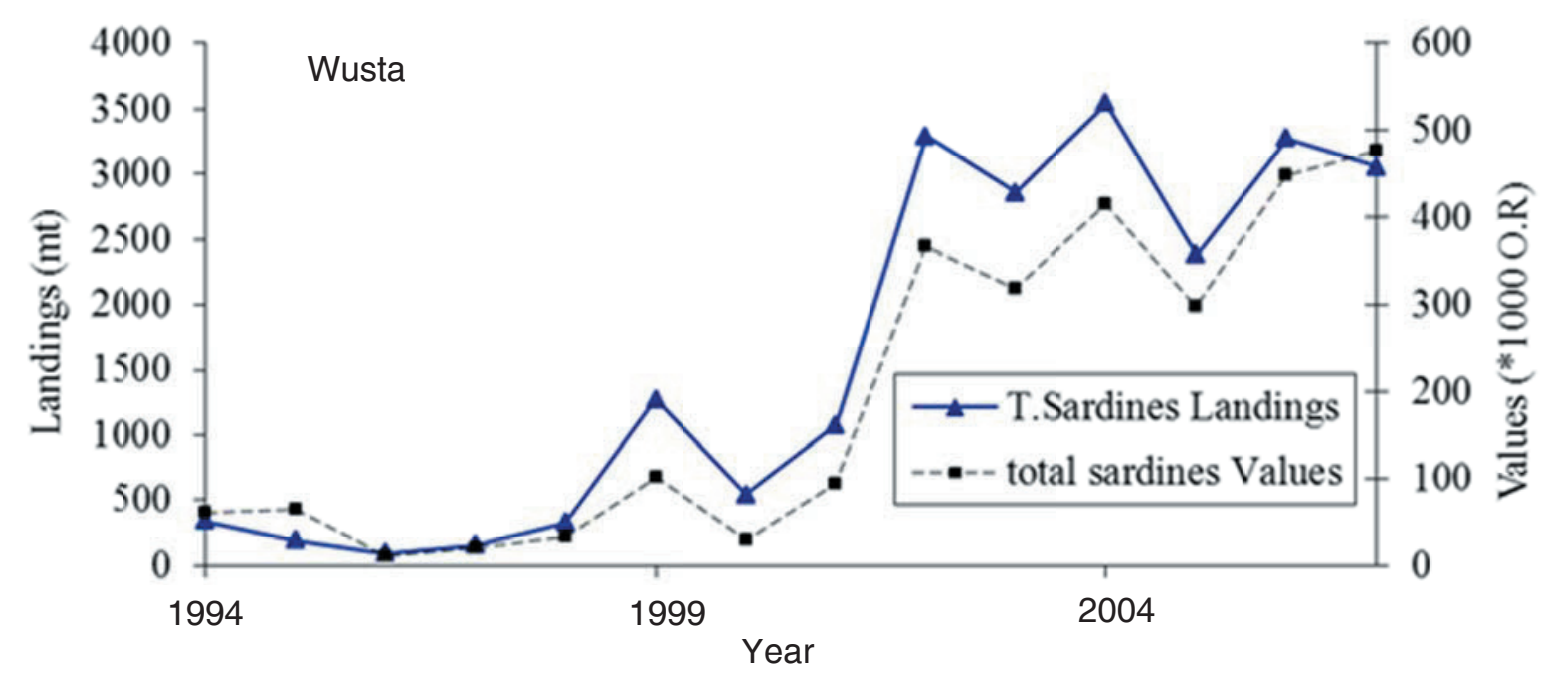

Figure 16. Total sardine landings (mt) and values (1000 R.O) in the Wusta region from the period 1994-2003. 


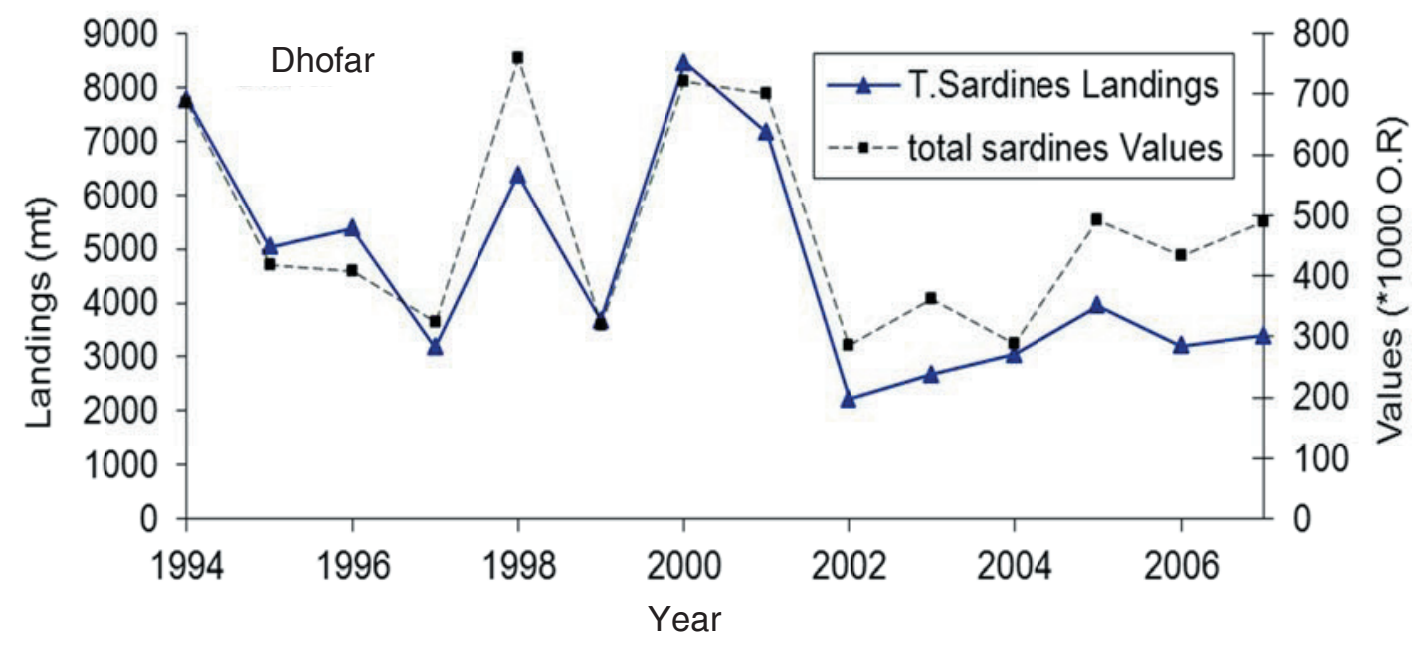

Figure 17. Total sardine landings (mt) and values (1000 R.O) in the Dhofar region from the period 1994-2003.

valued at 720,000 Omani Rials. The lowest was in 2002 which was 2,219 $\mathrm{mt}$ only, (287,000 Omani Rials). The highest value was experienced in 2001 when the total sardine landings in Dhofar was 6,375 $\mathrm{mt}$ with a total value of 759,000 Omani Rials (Fig. 17).

In the Al-Wusta and Dhofar regions, the fishermen stop fishing for sardines from June to August, when the sea conditions are too rough for fishermen to operate their traditional gear. But not all the fishermen follow this pattern. In some places, fishermen can still fish for sardine even during the monsoon (Al-Jufaili et al., 2006).

\section{Conclusions and Recommendations}

From the catch statistics, it is apparent that though the introduction of modern gear like purse seines has increased the area of the fishing grounds, this has not enhanced sardine production. Also, fluctuations in the catches are not due to fishing but due to fisheryindependent environmental factors such as the coastal drifts, upwellings, monsoon rainfall, temperature, salinity, $\mathrm{pH}$, fertility and the productivity of the water.

A time series analysis on the relationships between catches, abundance indexes, fishing effort and environmental parameters such as temperature, sea level, air temperature and rainfall are recommended for the rational exploitation of sardine resources. Since the various aspects of the biology of sardine, such as spawning, growth, density of population, migration and recruitment to the fishery are under the influence of the environment, continuous monitoring of data pertaining to the fish and its surroundings are essential to understand the dynamics behind it and to evolve appropriate prediction systems.

The quality of dried fish is very poor, and this could be significantly improved through a number of simple and inexpensive means. However, the margins for increased production costs are narrow, and only further investigation will prove if this will be economically viable.

\section{References}

Al-Jufaili S.M., A.R. Al-Azri, and S.S. Al-Shuaily. 2006. A preliminary investigation on the Omani sardines and anchovies stock fluctuation: Recommendations for future studies. Pakistan Journal of Biological Sciences 9:1073-1082.

Dorr, J.A. 1990. Small Pelagics Final Report. Project Report to the CIFADMSFC Small Pelagic Fish Research Programme. Ministry of Agriculture and Fisheries. Muscat, Sultanate of Oman. 63pp plus addenda.

Dorr, J.A. 1991. Small Pelagics Final Report for the Contract for Technical Services for Staffing the Marine Science and Fisheries Center. Project No.272-0101.1-1.

Harrington, J.M., R.A. Myers, and A.A. Rosenberg. 2005. Wasted fishery resources: discarded by-catch in the USA. Fish and Fisheries 6:350-361.

MAF. 1991. Feasibility Study on Facilities for Improved Sardine Drying. Fisheries Development Ltd. in association with Natural Resources Institute, Sultanate of Oman.

MAF. 1994. Feasibility Study on Facilities for Improved Sardine Drying. Fisheries Development Ltd. in association with Natural Resources Institute, Sultanate of Oman.

MAF. 1994-2007. Annual Statistics Report. Ministry of Agriculture and Fisheries Directorate, Oman.

MAF. 1995. Annual Statistics Report. Ministry of Agriculture and Fisheries Directorate, Oman.

Mahgoub, O., I.T. Kadim, S.M. Al-Jufaili, N.M. Al-Saqry, K. Annamalai, and A. Ritchie. 2005. Evaluation of sundried sardines as a protein supplement for Omani sheep. Animal Feed Science and Technology 120:245-257.

Randall, J.E. 1995. The Complete Divers' and Fishermen's Guide to Coastal Fishes of Oman. Crawford House Publishing, Bathurst, Australia. 2795. pp 63-68.

Siddeek, M.S.M., H.N.Al-Habsi., S.M.Al-Jufaily, and I.N. AlGhafry. 1994. Spawning cycle, recruitment patterns, and 
maturity length of Indian oil sardine at Al-Azaiba, in the Gulf of Oman. In: L.M. Chou et al., (Editors), 484487. The Third Asian Fisheries Forum at Singapore.

Stengel, H. and A. Al Harthy. 2002. The Traditional Fishery of the Sultanate of Oman (Fishing Gear and Methods). Muscat: Ministry of Agriculture and Fisheries, Directororate General of Fisheries Resources, Marine Science and Fisheries Center. p. 1-147.

Received: September 18, 2011

Accepted: November 13, 2011 